\title{
Ultrastructural Effects of the Propineb on Brain of Fetuses During Rat Pregnancy
}

\author{
Efectos Ultraestructurales de Propineb en el Cerebro de Fetos Durante el Embarazo de Ratón
}

Ekinci, C.*; Tahaoglu, A. E.**; Yavuz, D*; Deveci, E."; Aktas, A..; Yilmaz, T."**; Yumusak, Ö.* \& Yükselmis, O."

EKINCI, C.; TAHAOGLU, A. E.; YAVUZ, D.; DEVECI, E.; AKTAS, A.; YILMAZ, T.; YUMUSAK, Ö. \& YÜKSELMIS, O. Ultrastructural effects of the propineb on brain of fetuses during rat pregnancy. Int. J. Morphol., 32(4):1467-1471, 2014.

SUMMARY: Propineb is a fungicide with a propylene-bis-dithiocarbamate structure. Pregnant Wistar rats were exposed to 400 ppm propineb concentrations in $5 \mathrm{ml}$ distilled water, 5 days per week until the end of pregnancy. The rats were treated with propineb for 16 days and the brains of litter rats were sacrificed at first day of birth after which their brains were collected. Ultrastructural examination of the brains of the fetuses and propineb-treated pregnant females revealed a variety of histopathological effects. We suggest that mitochondrial damage may be an effective factor for neuron necrosis. These results supported the proposal that the exposure to fungicides such as propineb and to other naturally occurring compounds which inhibit mitochondrial function, may contribute to Parkinson's disease development.

KEY WORDS: Propineb; Electron microscopy; Neonatal rats; Brain.

\section{INTRODUCTION}

Dithiocarbamate fungicides are widely used against various plant pathogenic fungicides. Determination of dithiocarbamate fungicides residues in the environment, food, and other materials is of great importance for their toxicological behavior. Maneb and zineb are ethylene-bisdithiocarbamate fungicides used all over the world to control plant pathologies. This class of fungicides exhibits a low mammalian acute toxicity, although some subchronic and chronic toxicological effects have been observed (Edwards et al., 1991). Both maneb and zineb have been shown to possess carcinogenic activity in rats but not in mice (Edwards et al.; Vachkova-Petrova et al., 1991). Toxic effects of ethylene-bis-dithiocarbamates are usually related to ethylene thiourea (ETU), a common contaminant and metabolite and degradation product of this class of fungicides. Toxicological studies of ETU have generally shown that its primary effect is on the thyroid gland, although its effects have also been observed on the liver (Kendrick et al., 1991). ETU inhibits thyroid peroxidase which leads to decreased circulating levels of thyroid hormone and a compensatory increased secretion by the pituitary of thyroid stimulating hormone (TSH) (Goyer, 1986). Chronic stimulation of the thyroid gland by TSH initially causes follicular cell proliferation and ultimately leads to follicular cell neoplasia (Wlostowski, 1992). Few studies have been carried out on the mechanisms of organometallic fungicide action or on the fate of fungicides in target organisms. However, many studies have been reported on the effects of heavy metals alone in a variety of organisms (Kendrick et al.). Exposure to most metals results in metal accumulation in certain tissues and organs of the exposed organisms. It is also known that metals may cause extensive damage to the organs where they accumulate. Zinc concentrations vary widely in different tissues, but $\mathrm{Zn}$ is well known to accumulate in two particular organs, namely liver and kidney, where they may cause biochemical and histopathological changes (Goyer; Wlostowski; Deveci et al., 1999). Zn is known to be essential for the prenatal growth and differentiation, and its deficiency causes fetal growth retardation (Sowa \& Steibert, 1985). The purpose of the present study was to histologically assess the teratogenic effects of propineb during pregnancy on neonatal rat brain.

\footnotetext{
* Department of Histology and Embryology, Faculty of Medicine, University of Dicle, Diyarbakır, Turkey.

** Diyarbakır Maternity and Children Hospital, Department of Obstetrics and Gynecology, Diyarbakır, Turkey.

**** Dicle University, School of Medicine, Department of Neurosurgery, Diyarbakır, Turkey.
} 


\section{MATERIAL AND METHOD}

Animals and treatment. Twenty pregnant female $(n=20)$ Wistar albino rats weighing 200-220 g were used. All the animals were individually housed in stainless steel cages at room temperature. The animals had free access to standard laboratory rat food pellet (purina rat chow). The animals were randomly divided into two groups (four animals for each exposure group and four females used as control). Females were mated with non-exposed males; the criterion used to identify mated females was the presence of spermatozoa in the vagina (day 0 of pregnancy). The litters in the control $(n=10)$ an experimental group $(n=10)$ were taken. All pregnant females were individually housed in stainless steel cages at room temperature. The animals had free access to standard laboratory rat food pellet and tap water. Acute oral LD50 (global standard measurement for toxicity is the LD50) for rats was found to be $8500 \mathrm{mg} / \mathrm{kg}$ (Sowa \& Steibert). The experimental pregnant females (day 16-21 of pregnancy) received 400 ppm propineb (tech.70 $\%$ purity obtained from Bayer and Hoechst-Schering, respectively) concentrations in $5 \mathrm{ml}$ distilled water 5 days per week until the end of pregnancy. The females were treated with propineb for 16 days and the brains of litter rats were sacrificed at first day of birth. The controls received only distilled water. The doses administered orally by gastric tube (helping toxicant injections orally) were calculated on the basis of initialbody weight of each animal (ppm=mg toxicant per $1 \mathrm{~kg}$ body weight).

Ultrasonographic Examination. All experimental gravids were examined daily by a radiologist using ultrasonography (USG). A real time USG (Toshiba SSA-270A) and 7.5 MHz linear transducer was used to detect cardiac activation and to count the number of fetuses. The gravid rats gave birth during the 21 st and 22 nd days of pregnancy.

Histological Examination. The animals were sacrificed by decapitation under ether anesthesia and the brain tissues were then quickly removed. The parietal cortexes of the brains were removed immediately and cut into small pieces. The pieces of the tissues were immediately placed in $2.5 \%$ glutaraldehyde, buffered for $4 \mathrm{~h}$, then fixed in $\mathrm{OsO}_{4}$ for $2 \mathrm{~h}$, dehydrated in graded ethanol, and embedded in araldite. Semithin sections of $1 \mu \mathrm{m}$ thick were cut and stained with methylene blue-azure II for light microscopic examination. Thin sections of $70 \mathrm{~nm}$ were stained with lead citrate-uranyl acetate and examined and photographed under Zeiss Electron microscope 9S. The significance of differences between appropriate pairs of data sets was assessed by the ANOVA test.

\section{RESULTS}

At ultrasonographic examination there were no resorbed fetuses or stillborns during or after propineb treatment. It was clearly seen that the body weights of the experimental group of litters were lower than those of the control $(p<0.01)$. In this study, we found that the body weights of both one-day-old litters and their propineb-treated mothers were lower than those of the controls, and the mean weights of fetal whole brain in the propineb group did not differ from those of the controls (see Table I). The pregnant rats exposed to $400 \mathrm{ppm}$ propineb for about two weeks had some macroscopic and microscopic effects. Unilateral ptosis was also observed in 8 pregnant rats following their exposure to $400 \mathrm{ppm}$ propineb. Another interesting macroscopic observation at this concentration was that the fungicide resulted in unilateral paralysis in the extremities of pregnant females, and they rarely got through pregnancy (Fig. 1). However, such effects were not observed with their born litters.

In the light microscopic examination, some of the remaining neurons appeared pyknotic and dark. These cells were typically polymorphic showing both epithelioid and fusiform shape (Fig. 2A). The cytoplasm was swollen and nuclei were present in the external granular layer. Some neurons became necrotic, and fragmented vacuoles were seen

Table I. Body weights of both 1 day-old litters each entry shows the mean value \pm S.D. of body weights (grams) and Brain weights of litters (mg), n:Control and experiment animal number.

\begin{tabular}{lcc}
\hline & $\begin{array}{c}\text { Mother control } \\
(\mathbf{n}=\mathbf{4})\end{array}$ & $\begin{array}{c}\text { Mother 400 } \mathbf{~ p p m} \text { propineb } \\
(\mathbf{n}=\mathbf{4})\end{array}$ \\
\cline { 2 - 3 } Mother body weights $(\mathbf{g})(\mathbf{n}=\mathbf{8})$ & $206.25 \pm 7.50$ & $181.25 \pm 6.50$ \\
Litters body weight $(\mathbf{g})(\mathbf{n = 2 0})$ & $7.27 \pm 0.328(\mathrm{n}=10)$ & $6.44 \pm 0.128(\mathrm{n}=10)$ \\
Brain weights $(\mathbf{m g})$ & $138.9 \pm 9.1(\mathrm{n}=10)$ & $139.8 \pm 10.6(\mathrm{n}=10)$ \\
\hline
\end{tabular}




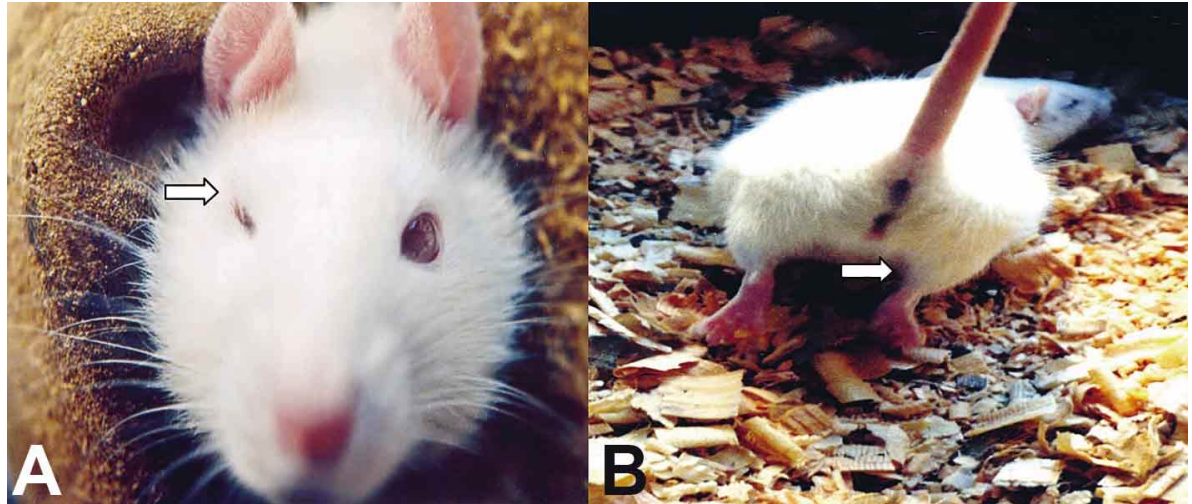

Fig. 1. A). Unilaterally, ptosis appearence at the end pregnancy (arrow). B). Unilaterally, paralysis observed (arrow).

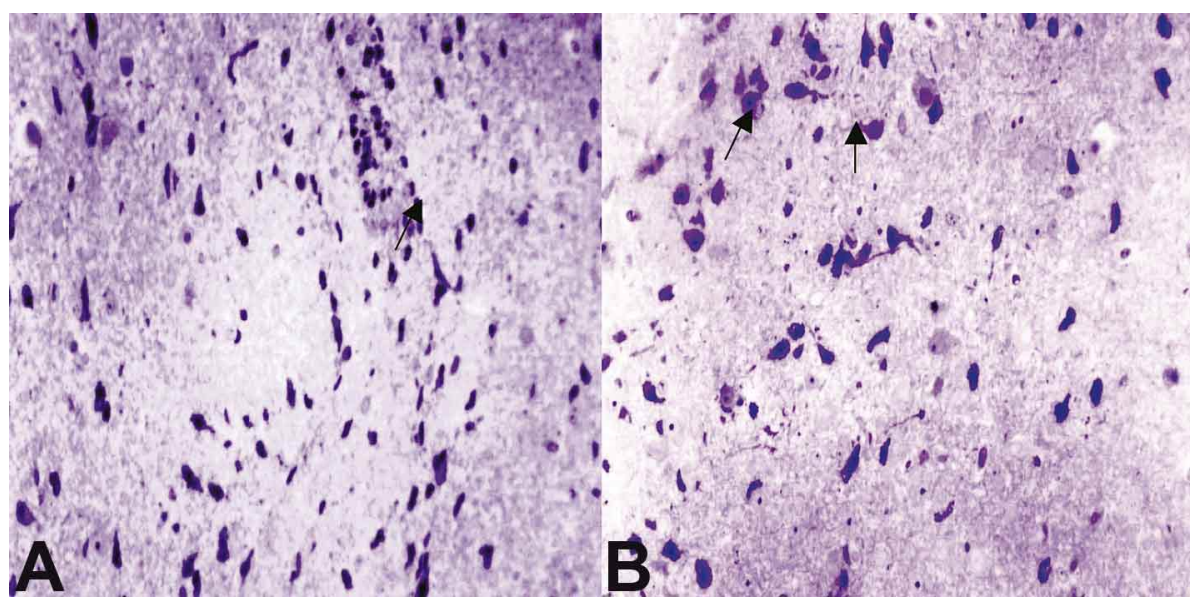

Fig. 2. A). Some of the remaining neurons appeared pyknotic and dark. These cells were typically polymorphic showing both epithelioid and fusiform shape (arrow) (Methylene blue-azure, X82). B). Cytoplasm swollen and nuclei present in the external granular layer; some neurons became necrotic (arrow) and fragmented vacuoles seen in the cytoplasm of neurogliocyte (Methylene blue-azure, X82).

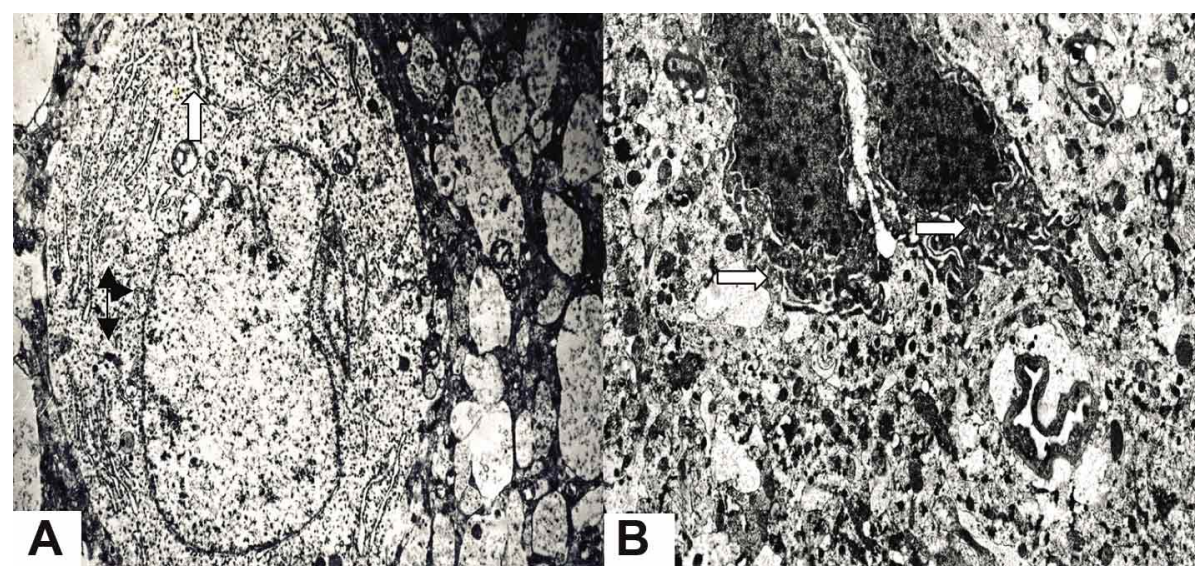

Fig. 3. A). Dilatation and irregularity of the cisternae of granular endoplasmic reticulum (thick arrow). Some mitochondria were normal, but swollen with degenerative changes (thin arrow) (Uranyl acetate-lead citrate- X8800). B). In the propineb-treated rat brain,The phagocytic microglial cells were enlarged with expanded were others cytoplasm and broad process. A increase in the number large secondary lysosomes in glial cells (arrow) (Uranylacetate, X6800). in the cytoplasm of neurogliocyte (Fig. 2B). Propineb-induced ultrastructural changes were observed in the parietal cortex neurons. The cerebral cortex of unexposed animals exhibited normal ultrastructure of all tissue elements. Some of the nuclei were irregular. The plasmalemma appeared disrupted and the regions of cytoplasmic clearing were seen. The perinuclear region showed few conspicuous organelles, usually including a few strands of endoplasmic reticulum and dilated Golgi apparatus. Swelling of the endoplasmic reticulum is an event which occurs during the propineb toxicity. The cytoplasm contained areas of low electron density. Numerous mitochondria with a swollen appearance were also found. Some mitochondria were normal, but the others were swollen with degenerative changes. Some mitochondria were extremely dilated with rupture of the outer mitochondrial membrane and aciculate rough surfaced endoplasmic reticulum (Fig. 3A). The phagocytic microglial cells were enlarged with expanded cytoplasm and broad process. An increase in the numbers of large secondary lysosomes was observed in glial cells (Fig. 3B).

\section{DISCUSSION}

Some fungicides were also reported to cause teratogenesis (Worthing, 1987; Beck, 1993; Price et al., 1996; Srivastava \& Raizada, 1996; Branch et al., 1996) and alterations in axial skeleton development in pesticide-treated mouse fetuses. Propineb has a low acute toxicity with a specific 
goitrogenic effect in rats. In repeated-dose toxicological studies, in addition to effects on the thyroid gland, reversible effects on skeletal muscles were described (Branch et al.; IPCS, 1999a, 1999b; Jones, 1999; Pauluhn, 1999). In these studies, no histopathological effects were found in the nervous system. However, the muscle degeneration may be indicative of peripheral neuronal degeneration or direct damage of the muscle. A subchronic study in Wistar rats showed that propineb results in behavioral changes as well as histochemical and ultrastructural changes in the brain (Vachkova-Petrova et al.). In this study, electron microscopy investigations demonstrated swollen mitochondria and accumulations of neurofibrillary material in the axo-somatic and axo-dendritic areas. Propineb was found to cause diarrhea in the pregnant female rats, which is a well-known clinical figure of acute $\mathrm{Zn}$ overload (Goyer). This may be one reason for the weight loss observed in female rats. Acute exposure to the organophosphate pesticide chlorpyrifos on gestation day 12 was found to cause changes in the maternal brain but lesser changes in the fetal brain (Chanda \& Pope, 1996). In the propineb group, the litter rats were observed with structural changes in the brain cortex cells along with pyknotic changes in the nuclei. The pregnant rats were administered with 400 ppm propineb for about two weeks had some macroscopic and microscopic effects. Ptosis was observed at the end of pregnancy (Fig. 1) following exposure to $400 \mathrm{ppm}$ propineb. Another interesting macroscopic observation at this concentration was that the fungicide caused a number of rare macroscopic changes throughout pregnancy. In our study we observed pyknosis in some of the remaining neurons and fragmented vacuoles in the cytoplasm of neurocyte. Endoplasmic reticulum was dilated and irregular in shape (Fig. 4). Swelling of the endoplasmic reticulum is an event which occurs during the propineb excitotoxicity. Growing evidence shows that mitochondrial dysfunction is an important factor in a cascade of neurotoxic events. We suggest that mitochondrial damage is probably an important factor in neuron necrosis.

\section{CONCLUSION}

These results support the proposal that exposure to fungicides such as propineb and to naturally occurring compounds that inhibit mitochondrial function may trigger Parkinson's disease. We conclude that these fungicides may affect the brain development and result in encephalopathy by crossing the placenta barrier in the litter rats.

EKINCI, C.; TAHAOGLU, A. E.; YAVUZ, D.; DEVECI, E.; AKTAS, A.; YILMAZ, T.; YUMUSAK, Ö. \& YÜKSELMIS, O. Efectos ultraestructurales de propineb en el cerebro de fetos de ratón durante la preñez. Int. J. Morphol., 32(4):1467-1471, 2014.

RESUMEN: El Propineb es un fungicida con una estructura de propileno-bis-ditiocarbamato. Ratas Wistar preñadas fueron expuestas a concentraciones de depropineb (400 ppm) en $5 \mathrm{ml}$ de agua destilada, 5 días por semana hasta el final de la preñez. Las ratas fueron tratadas por 16 días y las crías fueron sacrificados el primer día de nacimiento para recolectar sus cerebros. El examen ultraestructural de los cerebros de los fetos y las hembras preñadas tratadas con propineb reveló una variedad de efectos histopatológicos. Sugerimos que el daño mitocondrial puede ser un factor eficaz para la necrosis neuronal. Estos resultados apoyaron la propuesta de que la exposición a los fungicidas tales como propineb y de otros compuestos de origen natural que inhiben la función mitocondrial, puede contribuir al desarrollo de la enfermedad de Parkinson.

PALABRAS CLAVE: Propineb; Microscopía electrónica; Ratas neonatales; Cerebro.

\section{REFERENCES}

Beck, S. L. Additional endpoints and overview of a mouse skeletal variant assay for detecting exposure to teratogens. Teratology, 47(2):147-57, 1993.

Branch, S.; Rogers, J. M.; Brownie, C. F. \& Chernoff, N. Supernumerary lumbar rib: manifestation of basic alteration in embryonic development of ribs. J. Appl. Toxicol., 16(2):1159, 1996.

Chanda, S. M. \& Pope, C. N. Neurochemical and neurobehavioral effects of repeated gestational exposure to chlorpyrifos in maternal and developing rats. Pharmacol. Biochem. Behav., 53(4):771-6, 1996.

Deveci, E.; Guven, K.; Bashan, M.; Onen, A. \& de Pomerai, D. The accumulation and histological effects of organometallic fungicides propineb and maneb in the livers of pregnant rats and their offspring. J. Toxicol. Sci., 24(2):79-85, 1999.

Edwards, I. R.; Ferry, D. G. \& Temple, W. A. Fungicides and related compounds. Hayes, Jr. W. J. \& Laws, Jr. E. R. (Eds.). Handbook of pesticide Toxicology. New York, Academic Pres, 1991. p.1409. 
Goyer, R. A. Toxic effects of metals. In: Amdur, M. O.; Doull, I. \& Klassen, E. D.(Eds.). Casarett and Doull's ToxicologyThe'basic science of poisons, $4^{\text {th }}$ ed. Pergamon Press, New York, 1986. pp.623-80.

IPCS (International Programme on Chemical Safety). Propineb. In: Pesticide residues in food-toxicology evaluations. Geneva, World Health Organisation, 1993. pp.369-81.

IPCS(International Programme on Chemical Safety). Propineb. In: Pesticide residues in food-Toxicology evalutions. Geneva, World Health Organisation, 1999.

Jones, R. D. Technical grade Antracol. A subchronic toxicity feeding study in beagle dog. Bayer Corp. Report No. BC8735 (EU Monograph in preparation), 1999.

Kendrick, M. J.; May, M. T.; Plishka, M. J. \& Robinson, K. D. Metals in Biological Systems. New York, London, Ellis Horwood, 1992. p.179.

Price, C. J.; Marr, M. C.; Myers, C. B.; Seely, J. C.; Heindel, J. J. \& Schwetz, B. A. The developmental toxicity of boric acid in rabbits. Fundam. Appl. Toxicol., 34(2):176-87, 1996.

Pauluhn, P. Pilot study of the subacute inhalation toxicity in rats (exposure 5-6 hours). LH30/Z 80VM 00705/1096 (c.n.: propineb). Bayer AG Report No. 28915 (EU Monograph in preparation), 1999.

Sowa, B. \& Steibert, E. Effect of oral cadmium administration to female rats during pregnancy on zinc, copper, and iron content in placenta, foetal liver, kidney, intestine, and brain. Arch. Toxicol., 56(4):256-62, 1985.

Srivastava, M. K. \& Raizada, R. B. Development effect of technical dimethoate in rats: maternal and fetal toxicity evaluation. Indian J. Exp. Biol., 34(4):329-33, 1996.

Vachkova-Petrova, R.; Vassileva, L.; Antov, G.; Choumkov, N.; Dontchev, N.; Stavreva, M.; Tyagounenko, E.; Dinoeva, S.; Halkova, J. \& Ivanova-Tchemichanska, L. Toxicologic evaluation of propyneb on the Wistar rat. J. Toxicol. Clin. Exp., 11(7-8):407-16, 1991.

Wlostowski, T. On metallothionein, cadmium, copper and zinc relationships in the liver and kidney of adult rats. Comp. Biochem. Physiol. C., 103(1):35-41, 1992.

Worthing, C. R. The Pesticide Manual. $8^{\text {th }}$ ed. Thornton Heath, The British Crop Protection Council, 1987.

\section{Correspondence to:}

Dr. Engin Deveci Dicle University Medical Faculty

Histology and Embryology

Dept. 21280

Diyarbakır

TURKEY

Email: engindeveci64@gmail.com

Received: 09-07-2014

Accepted: 12-09-2014 